\title{
Petrologic and structural features of basement rocks of parts of Mukuru area, southeastern Nigeria
}

\author{
Ndukauba Egesi, Victor U. Ukaegbu \\ Department of Geology, University of Port Harcourt, Port Harcourt, Nigeria \\ Email address: \\ ndukauba.egesi@uniport.edu.ng (N. Egesi),vuukaegbu@yahoo.com (V. U. Ukaegbu)
}

\section{To cite this article:}

Ndukauba Egesi, Victor U. Ukaegbu. Petrologic and Structural Features of Basement Rocks of Parts of Mukuru Area, Southeastern Nigeria. Earth Science. Vol. 2, No. 4, 2013, pp. 96-103. doi: 10.11648/j.earth.20130204.11

\begin{abstract}
Field investigations in the western part of Mukuru area indicate intense structural imprints and high HT/HP metamorphism, and some magmatism. The rock units in the area include migmatitic gneisses, granulites, amphibolites, schists, charnockites, epidiorites and granites. The charnockites which are common in the shear zone and boundary areas appear to mark the end of magmatism. However, relicts of magmatic rocks mapped at Ubong Community in the study area suggest earlier magmatism. The metamorphic rocks are strongly deformed in a N-S to NE-SW direction with ghost structures, pinch and swell structures, ptygmatic veins, showing evidence of extensional tectonics. No visible contact relationship between the migmatitic gneisses and schists was observed. Diagnostic metamorphic structures like fine banding/layering of alternating dark- and light-coloured layers are conspicuous in gneisses and some amphibolites while schistosity and deep weathering are present in schists. The geodynamic features prevalent in Mukuru area are deformation and metamorphism. They indicate a possible petrogenetic link to southern Obudu Plateau in the north, western Cameroon in the east than Bansara in the west.
\end{abstract}

Keywords: Rock Types, Deformation, Structural Features, Metamorphism, Magmatism, Mukuru SE, Nigeria

\section{Introduction}

Mukuru sheet is located east of Boki Local Government Area, Cross River State, Nigeria. The western part of the study area is bounded by latitude $6^{0} 10^{1}$ to $6^{0} 30^{1} \mathrm{~N}$ and longitude $9^{0} 00^{1}$ to $9^{0} 11^{1} \mathrm{E}$ and flanked in the NE-SW by an elongated rifted depression, the Benue Trough and on the southeast by the prominent Cameroon Volcanic Line (CVL) (Ekwueme, 1987; Edet et al., 1994) (Fig.1) Thick equatorial rainforest of Oban Massif and Bansara area and the rugged Obudu Plateau topography have remained a barrier to detailed geological studies (Egesi and Ukaegbu, $2010 \mathrm{a} \& \mathrm{~b})$. Geologically, it is part of western prolongation of the reactivated Precambrian Pan-African tectonothermal belt of the West African craton to the left and Gabon-Congo Craton (GCC), to the east (Ukaegbu, 2003). The area is predominantly composed of highly deformed continuous $\mathrm{N}-\mathrm{S}$ trending polymetamorphic rocks comprising migmatitic gneisses, schists, amphibolites and undeformed charnockites and less of eclogites, epidiorites and granites. The area was probably subjected to strong collision process, which gave rise to high pressure, high temperature upper amphibolite-granulite rocks, with strong imprints of the N-
S and NE-SW Pan-African Orogeny. This research attempts, to present insight into petrogenetic and geotectonic history of the Mukuru area of the Bamenda Massif.

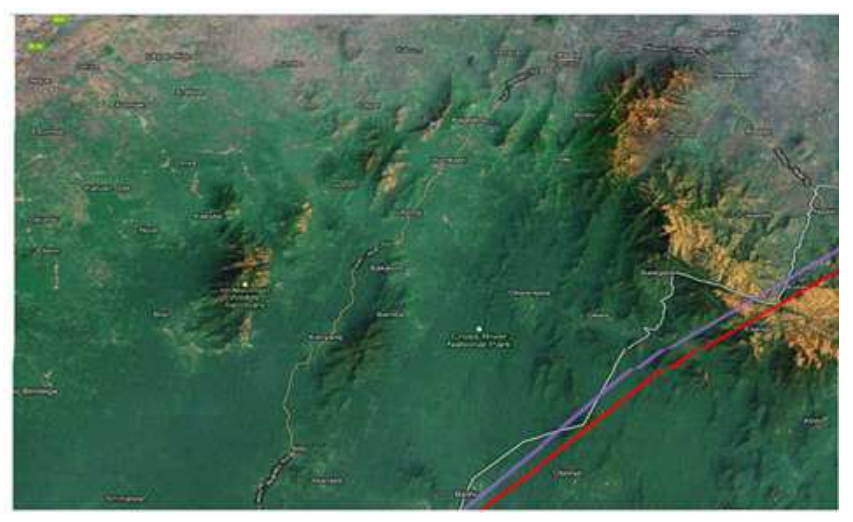

Fig.1. Remote sensing map of study area with the prominent Cameroon Volcanic Line in red (Google Earth 2011)

\section{Geological Setting}

Mukuru sheet (305 NW \& SW) are parts of the larger Bamenda Massif of the Cameroon. The rock types which 
form the boundary area with Bansara are charnockites. The charnockites form massive chain of hills, from Buanchor to Bakum as far as Okorshie in southwestern parts of Obudu area and separate the granulites rocks of Kanyang, Wula, Bakalum, and Bamba areas.(Fig.2) The amphibolites form large exposures at Okiro and Ubong areas, showing outcrops of epidorites between Okiro, Ubong and Bakum areas. The amphibolites become schistose northwards at Ofambe and Begiagbah areas where they form high plateaux and hills. At the Cross River National Park, Butatong field office, there is an exposure of schists which have been highly deformed and weathered, extending into Bemi River which contain alluvium deposits. The Bemi River flowing in a N-S direction forms the buffer zone boundary with none buffer zone. The river is about $30 \mathrm{~km}$ to Okwangwo and $60 \mathrm{~km}$ to Okwa area boundary with Takamanda National Park in Cameroon. The general trend of structures follows the other already established patterns in other parts of the reactivated Basement Complex of Nigeria (Orajaka, 1964; Rahaman, 1976; Grant, 1978; Ekwueme, 1987; 1994, Ukaegbu, 2003; Ukaegbu and Oti, 2005, Egesi and Ukaegbu, $2010 \mathrm{a \& b}$ ). The metamorphic rock units consist of migmatitic gneisses with structures like folds (open, isoclinal, gentle to tight), granulite complex, schists and amphibolites. The granulite metamorphism probably was repeated/polycyclic, leading to formation of retrogressed granulites and amphibolites. This is similar to the classical regions for poly metamorphism like the Lewisian Complex of NW Scotland and the Lewisian Complex of West Greenland, with the following metamorphism episodes:-

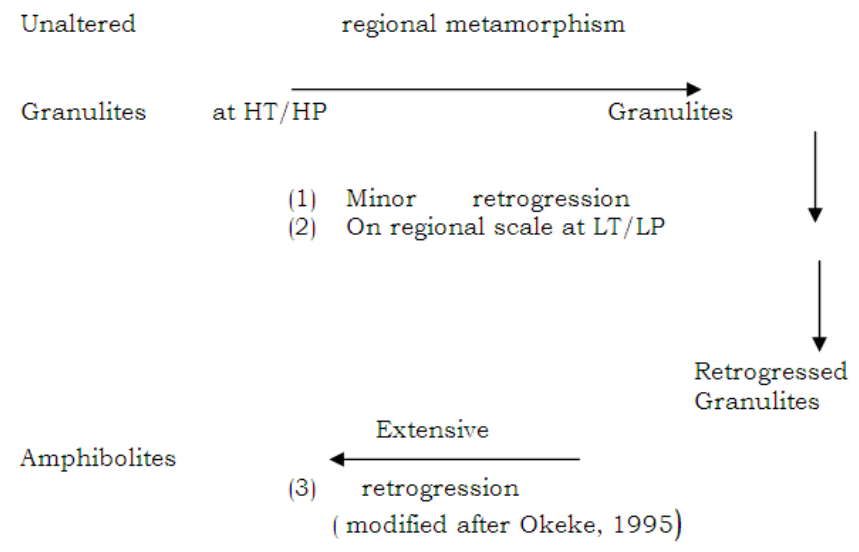

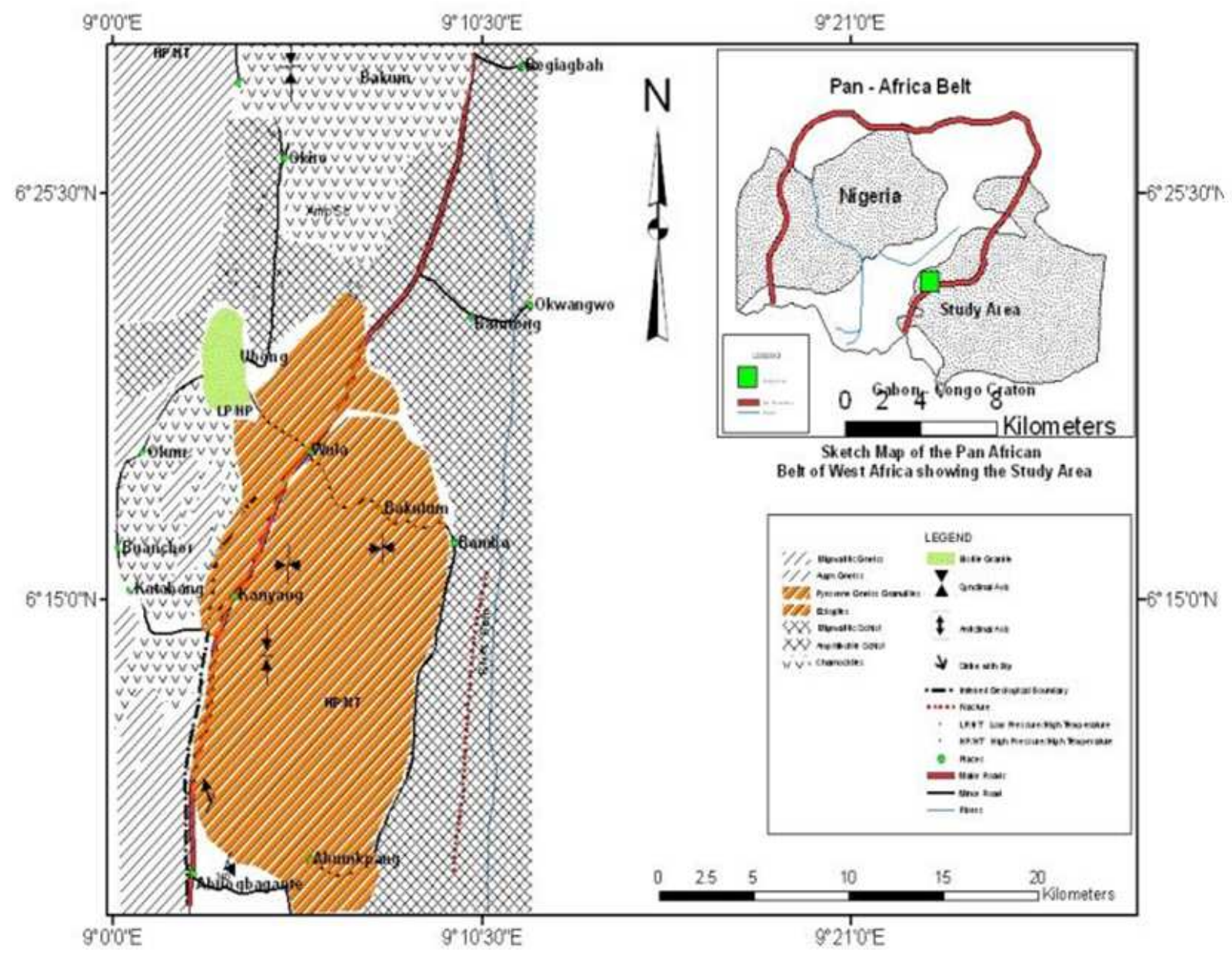

Fig. 2. Geological Map of Parts of Mukuru, Boki, South Eastern Nigeria 


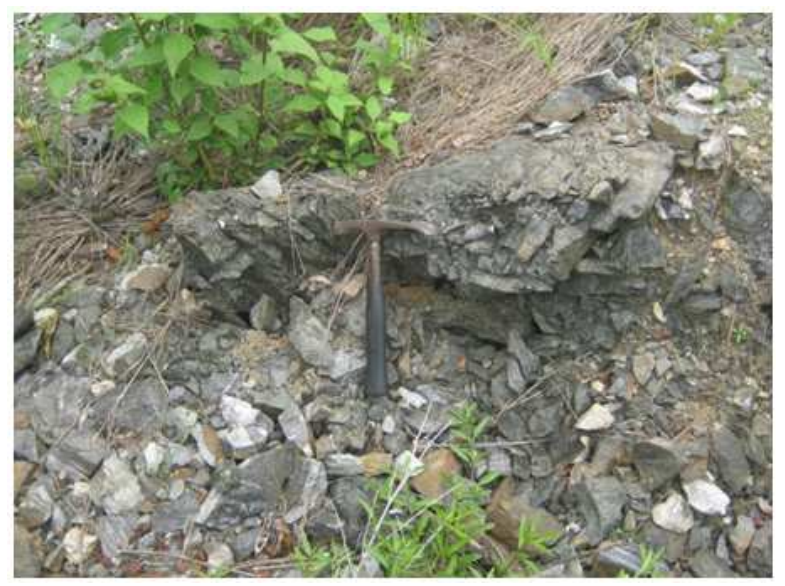

Fig.3. Eclogite occurring as a dyke from a pipe at Kanyang

\subsection{Petrology}

Mukuru sheet $305 \mathrm{NW}$ and SW consist of minor biotite granites at Ubong area, extensive charnockcites from Buanchor to Olum, Bakum as far as Okorshie in the north which is in Obudu sheet 291 SW (Figs. 4 and 5).

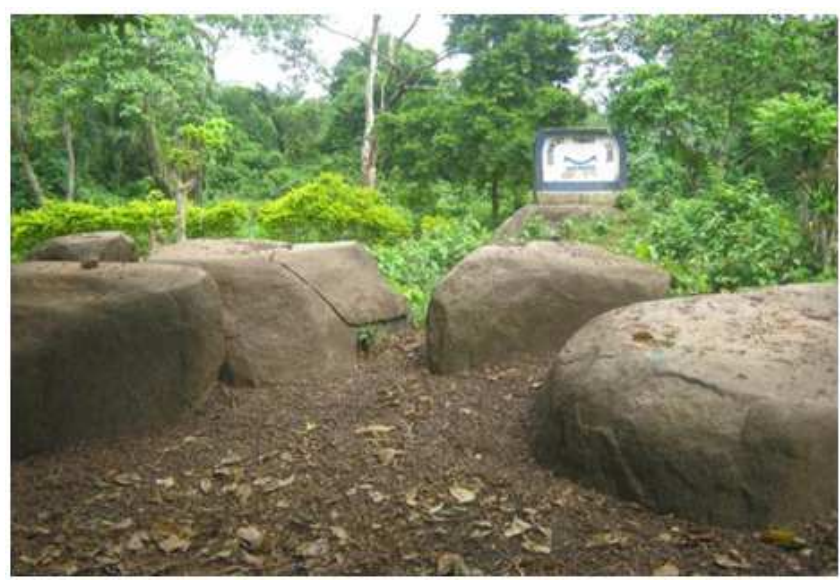

Fig.4a. Biotite Granite at Ubong area

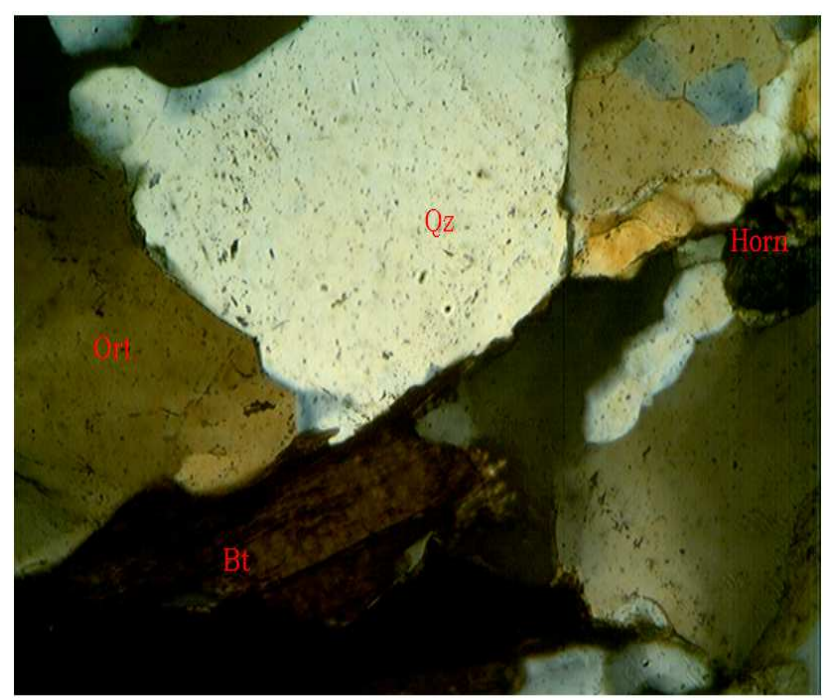

Fig.4b. Photomicrograph of Biotite Granite at Ubong area showing quartz, orthoclase, hornblende and biotite.

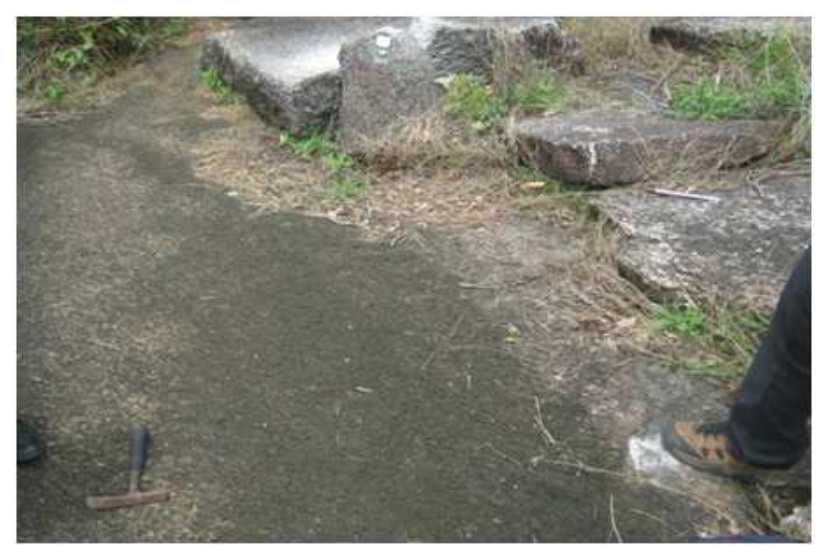

Fig.5a. Charnokite undergoing exfoliation weathering at Bakum hills at $214 m$

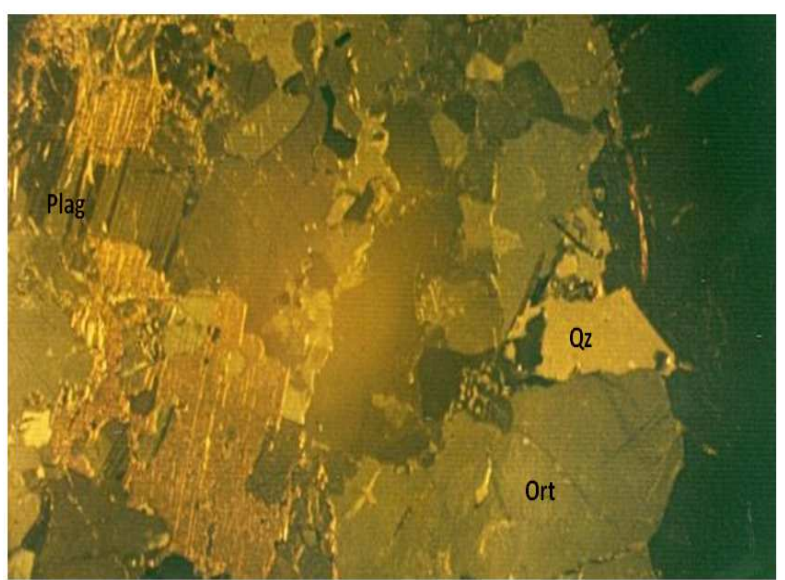

Fig.5b. This photomicrograph is porphyritic texture with brownish Feldspar and quartz (X 40).

The amphibolites exhibit black to dark green colour, and have medium to coarse-grained texture with well developed foliation at Ubong, Okiro Ubang, Begiagbah and Bamba areas (Figs 6,7,8,9 and 10). They are relatively massive and hard so that small-scale folds are rarely developed. The hornblende schists form highlands at Ofambe and Olum areas (Figs.11, 12 and 13). Schists are also extensive and deeply weathered and deformed on the lowland areas from Butatong to Okwangwo areas.

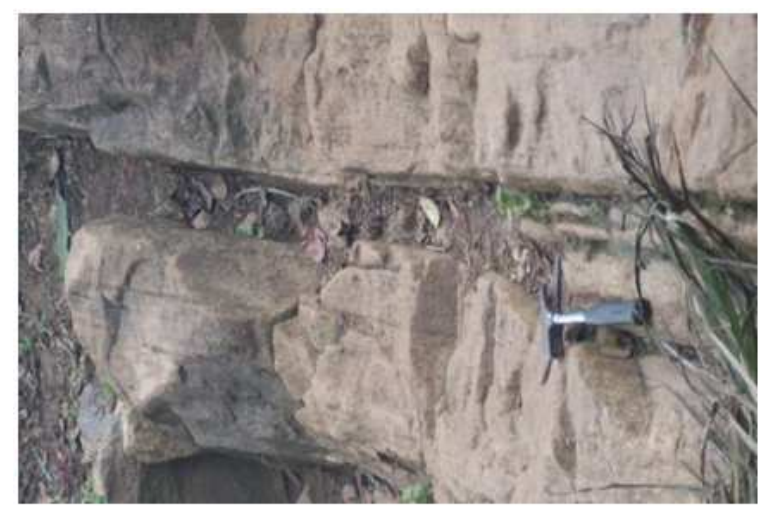

Fig.6. Hornblende schist at Ubong 


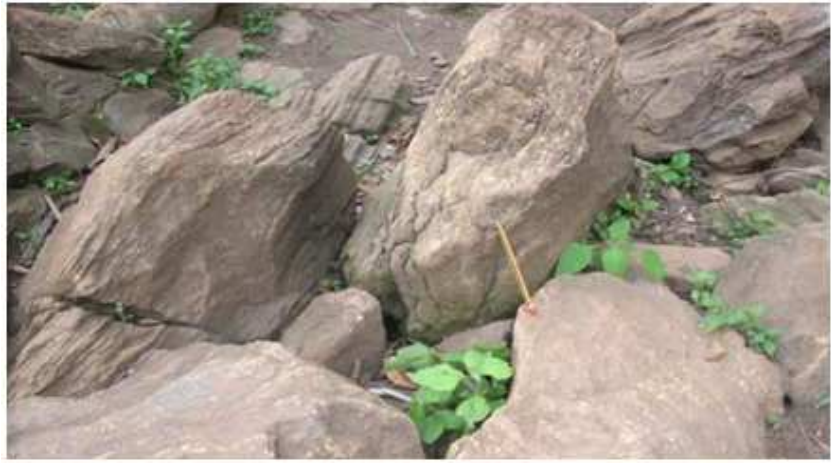

Fig. 7. Hornblende schist highly fractured and dismembered at Ubong

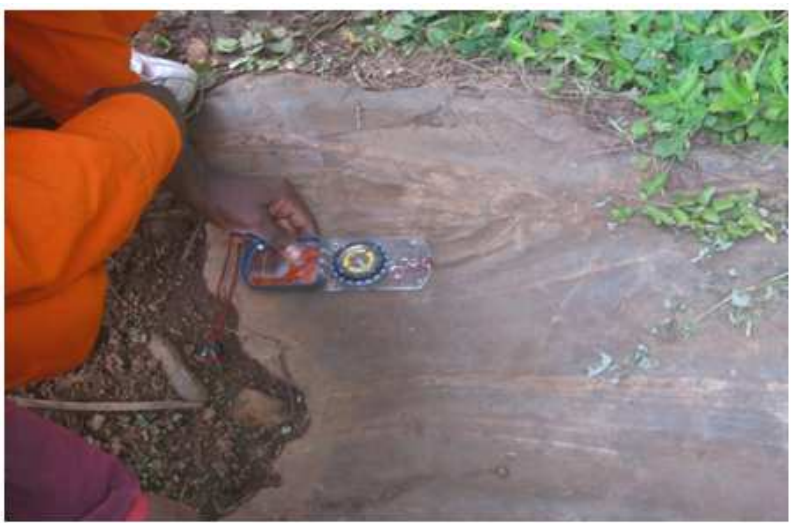

Fig.8a. Hornblende schist or Folded hornblende Schist at Begiagbah

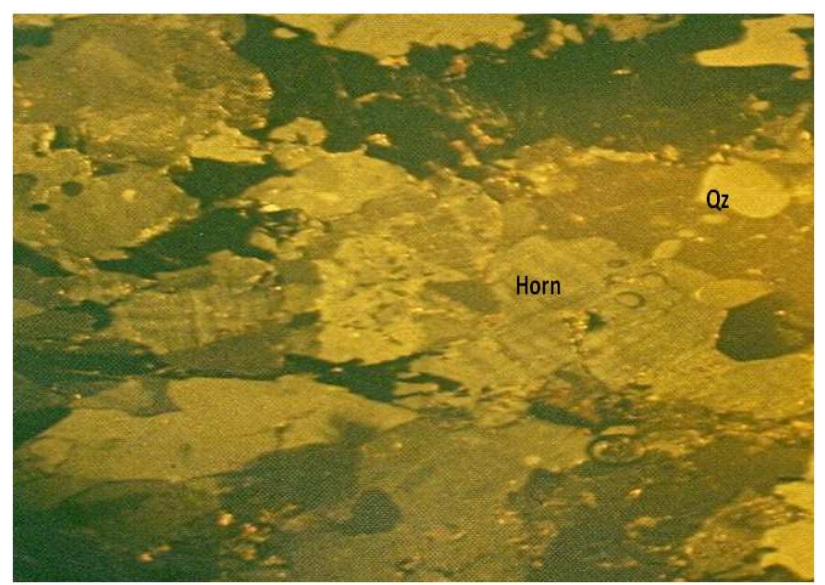

Fig. 8b. Photomicrograph of hornblende schist with hornblende twinning (XPL 40)

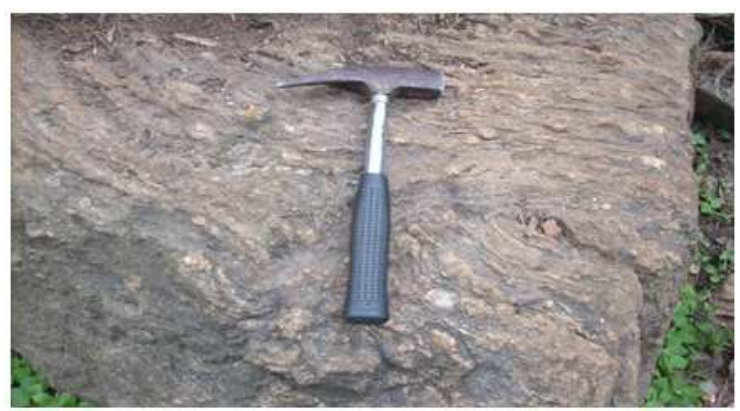

Fig. 9a. Amphibolite(Epidiorite) foliated with garnet porphyroblast at Ubong

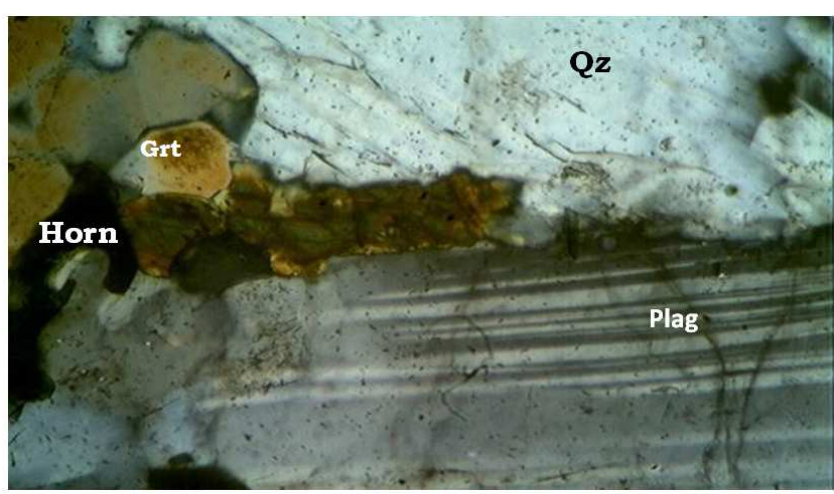

Fig.9b. Photomicrograph showing Plagioclase, quartz, garnet, hornblende XPL40

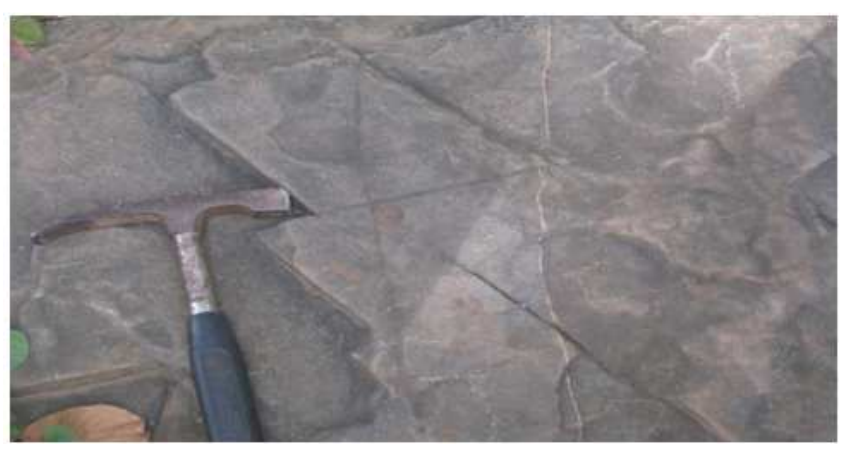

Fig.10a. Amphibolites homogeneous with longitudinal joints at Begiagbah

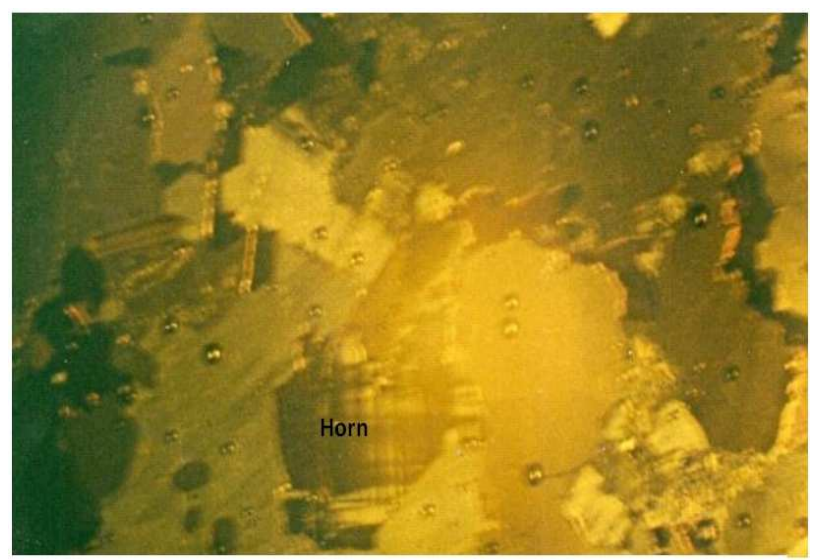

Fig 10b. Photomicrograph of Amphibolites at Begiagbah

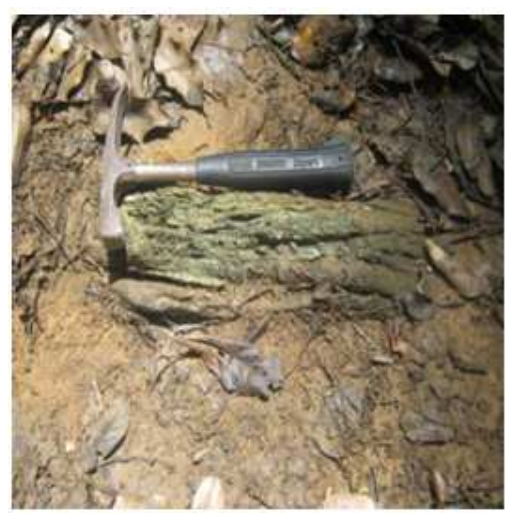

Fig.11. Migmatitic Schist highly weathered in none buffer zone near Bemi river 


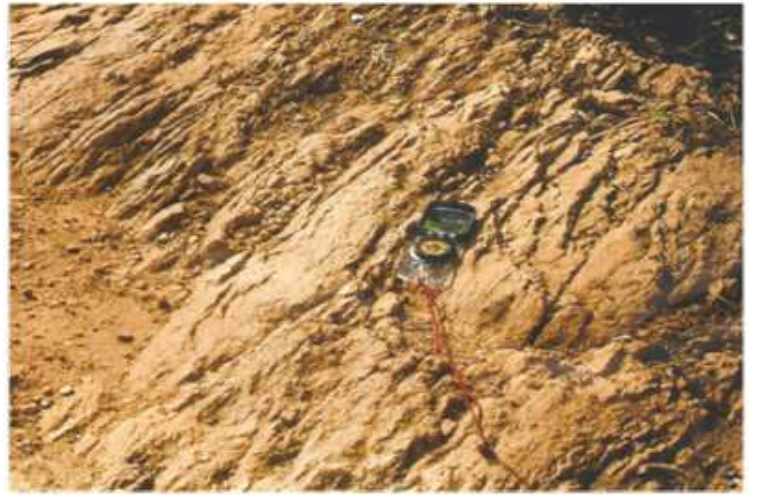

Fig.12. Fractured and highly weathered migmatitic schist along Olum road

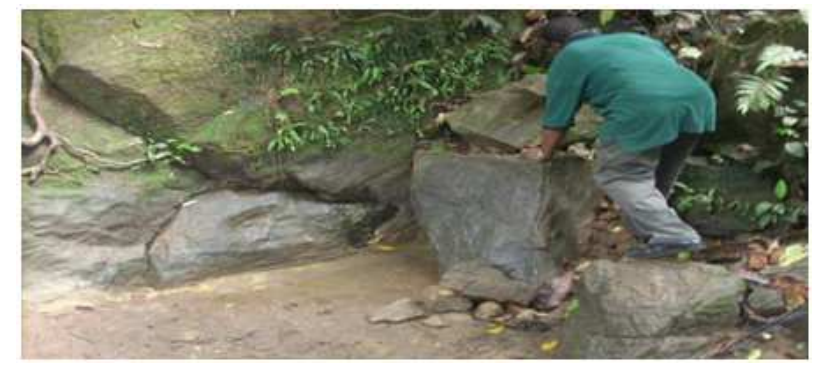

Fig.13. Water seepage from fractures in schist at Olum

Granulites were mapped at Kanyang, Wula, Bakalum, Bamba and Abuogbagante areas. Retrogressed granulites as well as migmatites gneisses were observed at Bamba and Bakalum areas Figs. 14,15,16,17, 18 and 19.

The modal composition of the rocks in the study area is shown on Table 1.

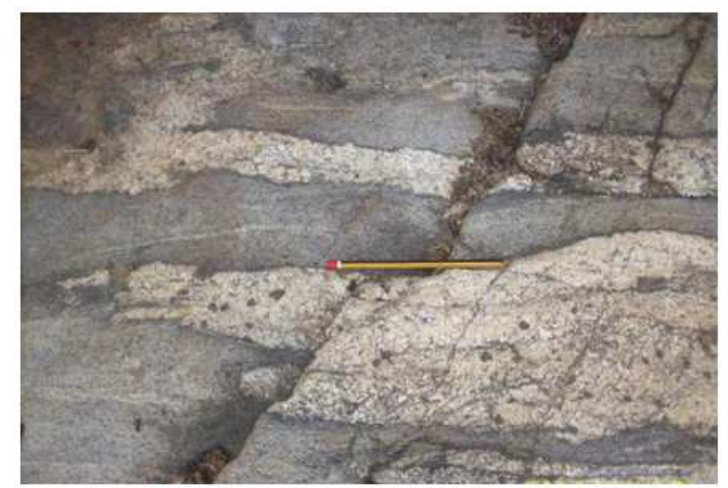

Fig.14. Migmatite gneiss at Kanyang

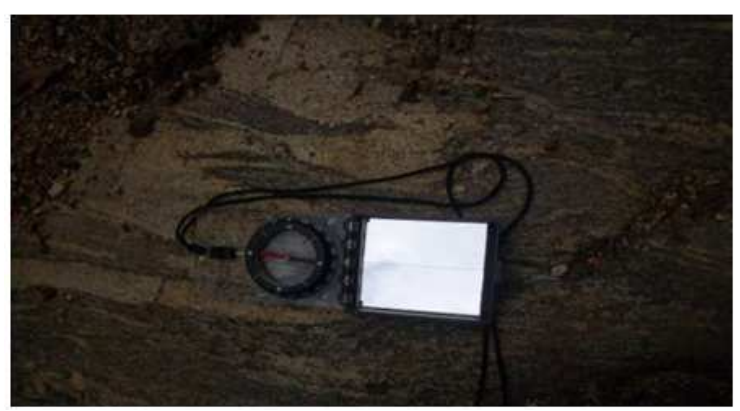

Fig. 15. Migmatitic gneiss with drag fold at Kanyang

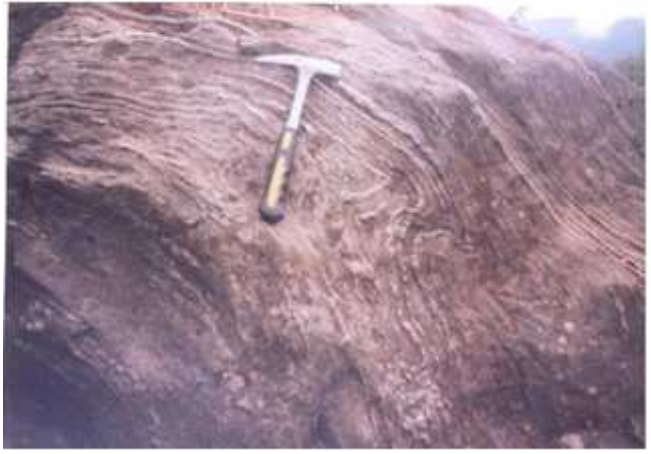

Fig 16a. Migmatitic Gneiss with small scale planar and linear features at Bamba

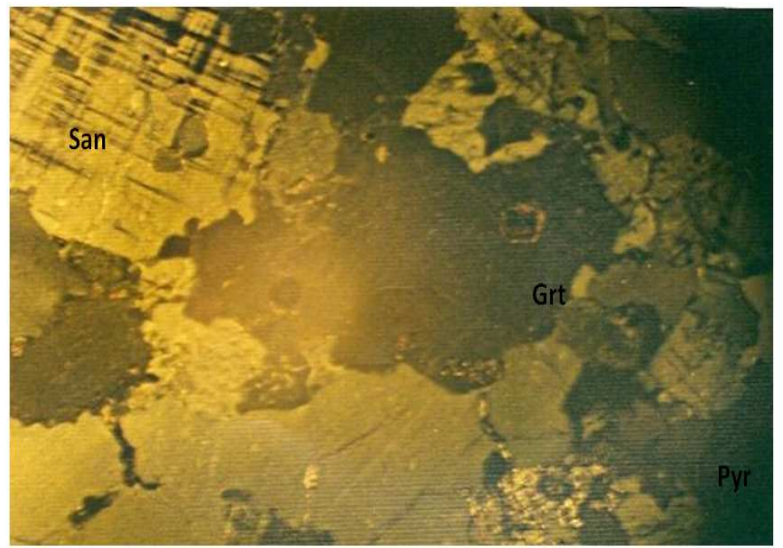

Fig. 16b. The crystal of pyroxene and Squat prisms of garnet at Bamba (X40)

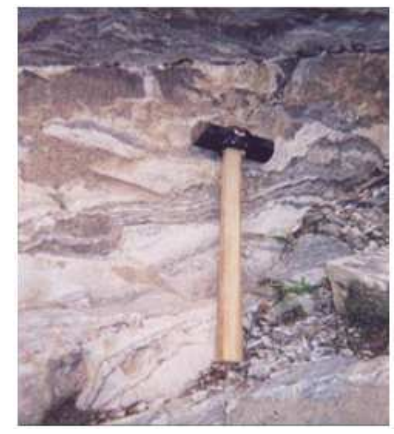

Fig. 17. Pinch and swell structures in Kanyang quarry

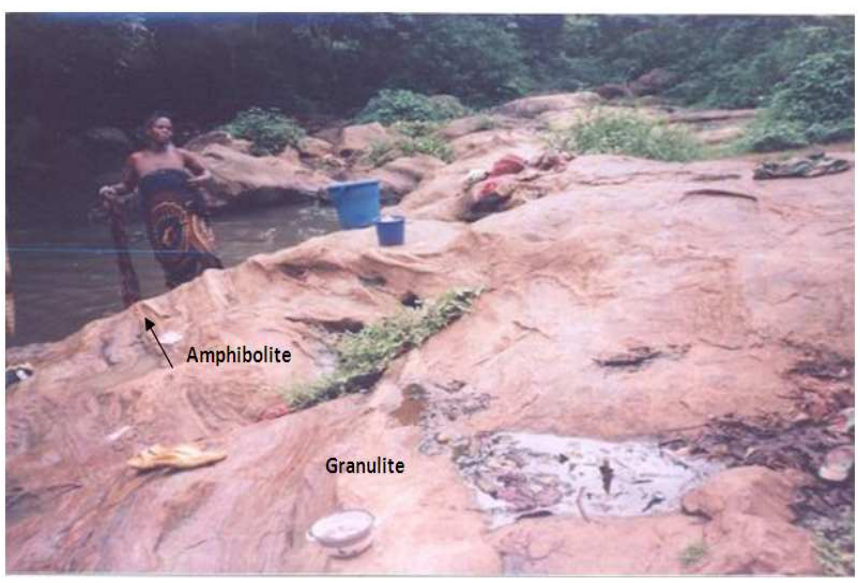

Fig. 18. Retrogressed Granulites at Bamba 


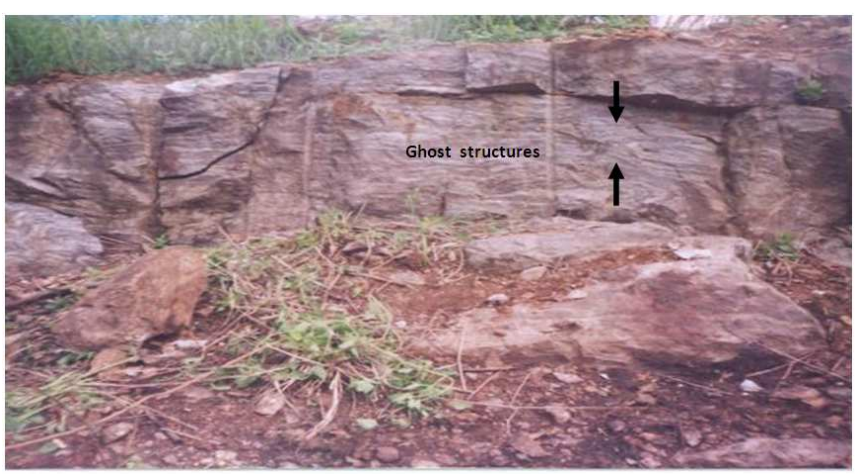

Fig. 19a. Granulite with Ghost structures at Kanyang 2

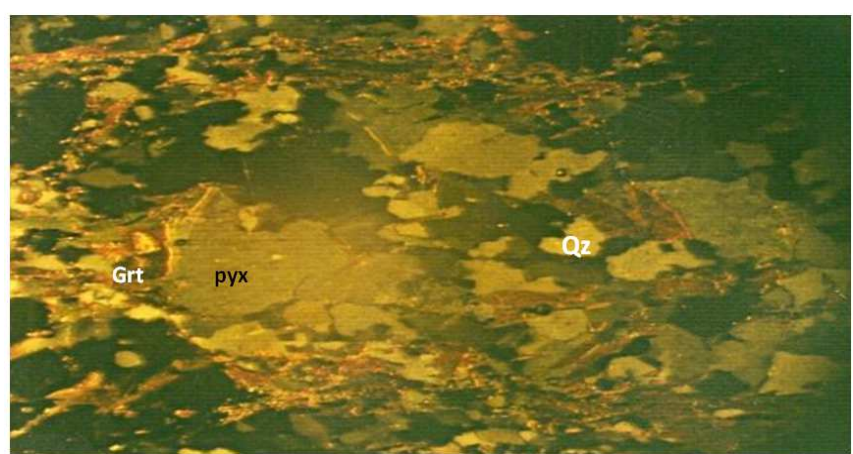

Fig. 19b. This rock contains mostly Pyroxene-hypersthene. The foliation is defined by aligned garnet mineral sandwiched between quartz grains. (X40)

Table 1: modal composition of rocks from mukuru

\begin{tabular}{|c|c|c|c|c|c|c|c|c|c|}
\hline Mineral & $\begin{array}{c}\text { Migmatitic } \\
\text { gneiss }\end{array}$ & $\begin{array}{c}\text { Pyroxene } \\
\text { gneiss }\end{array}$ & $\begin{array}{l}\text { Augen } \\
\text { gneiss }\end{array}$ & Eclogite & Schist & Amphibolite & Granite & Epidiorite & Charnockite \\
\hline Quartz & 30 & 23 & 35 & $<1$ & 27 & 3 & 27 & 3 & 22 \\
\hline K-feldspar & 22 & 15 & 17 & - & 10 & - & 23 & - & 32 \\
\hline Plagioclase & 15 & 25 & 22 & 15 & 20 & 18 & 18 & 20 & 18 \\
\hline Biotite & 13 & 10 & 8 & 3 & 21 & 10 & 10 & 12 & 5 \\
\hline Muscovite & 7 & - & 6 & - & 7 & - & 7 & - & - \\
\hline Chlorite & - & - & - & - & - & - & - & - & - \\
\hline Hornblende & 6 & - & 6 & - & 7 & 62 & 4 & 60 & 5 \\
\hline Orthopyroxene & $\mathrm{T}$ & 15 & - & - & - & - & - & - & 15 \\
\hline Clinopyroxene & $\mathrm{T}$ & - & - & 35 & - & 3 & - & 5 & - \\
\hline Garnet & 3 & 8 & 7 & 45 & 4 & 5 & - & - & 2 \\
\hline Olivine & - & - & - & - & - & $<1$ & - & - & - \\
\hline Kyanite & - & - & - & - & 3 & - & - & - & - \\
\hline Sillimanite & - & 10 & - & - & - & - & - & - & - \\
\hline Myrmekite & - & - & - & - & - & - & 7 & - & - \\
\hline Perthite & - & - & 3 & - & - & - & $<1$ & - & - \\
\hline $\begin{array}{c}\text { Opaque } \\
\text { minerals }\end{array}$ & 3 & 3 & 2 & - & $<1$ & 4 & 3 & - & $\mathrm{T}$ \\
\hline
\end{tabular}

\section{Structural Geology}

The extensive charnockitic rocks seem to have terminated the massive igneous activities observed in Bansara area. The major structural features in Mukuru area is the Mbe mountain belt which includes Kanyang hills, Bakalum hills, Abuogbangante hills, Abumkpang hills Bamba hills, while Bakum hills, Begiagbah hills and Ubong hills are parts of Afi mountain. The rocks in the area are metamorphosed, deformed without any visible magmatic structures. However, boitite granites were mapped in a restricted occurrence at Ubong area which is in close proximity to the Bansara/Mukuru boundary areas (Figs 1 and 2).

\section{Planar structures}

The banding in the gneisses is irregular and foliation is well defined. Quartz and feldspars (perthites and antiperthites) are pre- dominant and micaceous minerals are lacking in the amphibolites, and hornblende schists display a fine banding at some locations and are less conspicous in amphibolites than in schists. Figs 6,7,8 and 10. The migmatites consist of gneiss and a granitic component which form layers or veins with clusters of feldspar and quartz grains. Swirling folds and completely flow creep veins are evidence that these rocks were probably "plastic" (Figs 5 and 15). 


\section{Linear structures}

Lineated, strongly schistose rocks which can help in the identification of the minerals present were map in the area. Hornblende and micas are common and these show segregation banding in the schists. The Mbe mountain belt, Buanchor hills, Bakum hills and several other highlands are in N-S to NE-SW trend which conforms with observed regional structures in Obudu area (Ekwume, 1987; Ukaegbu and Oti, 2005). The ghost structures in granulites is in a N-S trend at Kanyang. The linear feature in migmatites are fold axes which are in E-W direction at Bamba. The Bemi River courses flow $\mathrm{N} 010^{\circ} \mathrm{E}$ is in N-S direction, and major faults lineaments are in a regional N-S directions (Figs. 20 and 21)

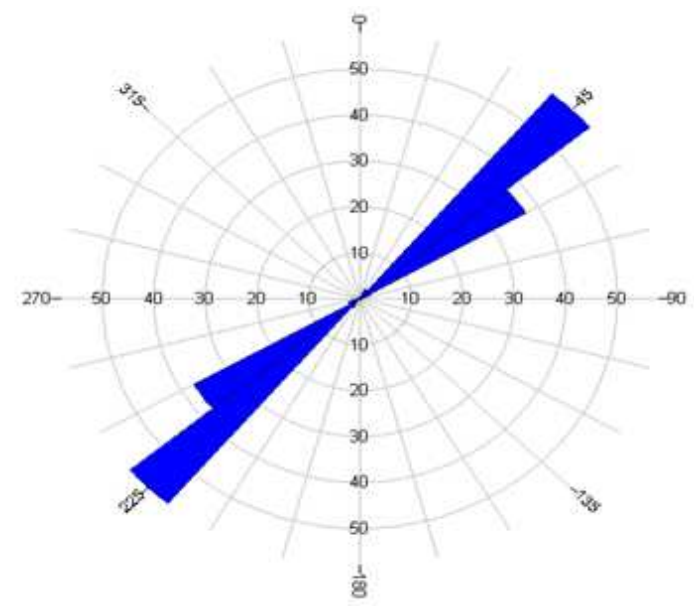

Fig.20. A Rose Diagram showing Fractures in NE-SW Direction at Kanyang

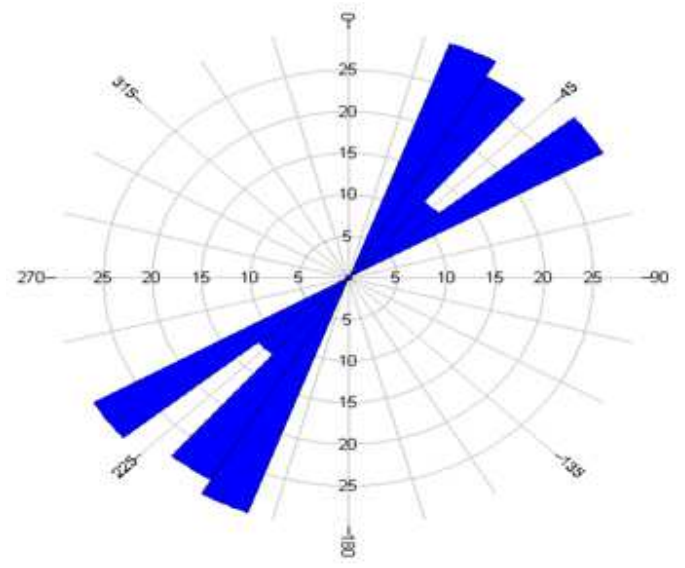

Fig. 21. Rose Diagram Showing Mineral Lineation in granulite at Kanyang

\section{Discussion}

Mukuru area consists mainly of metamorphic rocks. The late to post Pan-African intrusives are absent in Mukuru. The geology appears to be similar to that of southern Obudu (sheet 291) which also lacks abundant granites (Ukaegbu, 2003). The ganitoids were emplaced into the metamorphic Basement Complex of Bansara/Mukuru boundary and also mark the terminal end of the Pan African event (Egesi and Ukaegbu, 2011).

The periphery of the Mukuru sheet is strongly defined by charnocktic rocks, which form highlands with exfoliation weathering of boulders, exposing fresh surfaces from the south Buanchor to Okorshie, in the north. The granulites do not extend to these charnockites on exposed surfaces, and they seem to demarcate the granulites terrain. There is no contact relationship between the migmatitic gneisses and schists revealed on the surface but spatial configurations of both rock types suggest that the schists may be relatively younger, and were probably supracrustals on the gneissic rocks. The amphibolites, which occurred as lense in granite gneisses at Agba Osokom in Bansara area, are relatively massive and hard to sample in Mukuru area. The rocks at Kanyang are granulite facies characterized by pyroxene while at Ubong/Okiro are amphibolite facies rocks with hornblende as the main component. Also, in the Ikpeshi area of Igarra schist belt southwestern Nigeria, rocks that have amphibolite facies mineralogy has been mapped by Faculty and students of the Department of Geology, University of Port Harcourt in 2009. The geodynamics features prevalent in the Mukuru area are deformation and metamorphism. They indicate a possible petrogenetic link to southern Obudu Plateau in the north, western Cameroon in the east than Bansara area in the west.

\section{Conclusion}

The structural relationships in Mukuru area are similar to those of Obudu Plateau but different from the Bansara area, in having granulites facies metamorphism, retrogressive metamorphism and amphibolites facies mineralogy. Deformation and metamorphism started earlier in the area and terminated with magmatism of the Bansara area. Rock types mapped in Mukuru have been classified on the basis of field, petrographical and mineralogical criteria as migmatitic gneiss, granulite, eclogite, migmatitic schist, amphibolites/hornblende schist, epidoirite and biotite granite.

\section{References}

[1] Edet A. E., Teme, S. S., Okereke, C. S., Esu, E. O., 1994. Lineament analysis for groundwater exploration in Precambrian Oban Massif and Obudu Plateau, SE Nigeria. Journal of Mining Geology Vol. 30, No. 1, pp. 87 - 95.

[2] Egesi, N. and Ukaegbu, V. U., 2010a. Trace and Rare Earth Element Geochemical Fingerprints on the Petrogenesis and Geotectonics of the Enderbite-Adamellite-Granite Complex in parts of Bansara (Sheet $304 \mathrm{NE}$ and SE), SE, Nigeria. The IUP J. of Earth Sciences Vol. 4 No.2:7-25 www.iupindia.org

[3] Egesi, N. and Ukaegbu, V. U., 2010b. Petrologic and Structural Characteristics of the Basement Units of Bansara Area, southeastern Nigeria. Pacific Journal of Science and $\begin{array}{lllll}\text { Technology } & \text { (PJST) } & 11(1): 510 \quad & - & 525 .\end{array}$ 
http://www.akamaiuniversity.us/PJST11_1_510.pd

[4] Egesi, N. and Ukaegbu, V. U., 2011. Petrology and Major Element Geochemistry of Late to Post Neoproterozoic Peraluminous Granitoids in parts of Bansara Southeastern Nigeria. The IUP J. of Earth Sciences Vol. 5 No. 3: 7-19 www.iupindia.org

[5] Ekwueme, B. N., 1987. Structural Orientations and Precambrian Deformational Episodes of Uwet Area, Oban massif SE Nigeria. Precambrian Res. 34: 269-289.

[6] Ekwueme, B. N., 1994. Structural features of southern Obudu Plateau, Bamenda massif, SE Nigeria: Preliminary interpretations. Journ. Mining Geol. Vol. 30. No. 1 pp. $45-$ 59.

[7] Goggle Earth 2011. Remote sensing map of study area with the prominent Cameroon Volcanic Line in NE-SW.

[8] Grant, N. K., 1978. Structural distinction between a sedimentary cover and underlying basement in 600Mya Pan-africa domain of North-western Nigeria, West Africa. Geo. Soc. Am. Bull. 89, 50 - 58.
[9] Orajaka, S., 1964. Geology of the Obudu area, Ogoja province, Eastern Nigeria. Le Naturaliste Canadian, Vol. XCL, No. 3, pp. $72-86$.

[10] Okeke, P.O., 1995. A handbook Metamorphic Geochemistry. Dulacs Press Enugu p.128

[11] Rahaman, M. A., 1976. Progressive Polyphase metamorphism in pelitic schist around Aiyetoro, Oyo State, Nigeria. Nig. Journ. Min. Geol. Vol. 13, No. 2, pp. 33 - 44.

[12] Toteu, S. F., Penaye, J., and Djomani, Y.P., 2004. Geodynamic Evolution of pan-African Belt in Central Africa with Special Reference to Cameroon. Can. J. Earth Sci. 41: 73-85.

[13] Ukaegbu, V. U., 2003. The Petrology and Geochemistry of parts of southern Obudu Plateau, Bamenda Massif southeastern Nigeria. Unpubl. Ph.D. Dissertation. Univ. of Port Harcourt, Nigeria p.321

[14] Ukaegbu, V. U. and Oti, M. N., 2005. Structural elements of the Pan-African Orogeny and their geodynamic implications in Obudu Plateau,southeastern Nigeria. [J]. Journ. Min. Geol. $41,41-49$. 